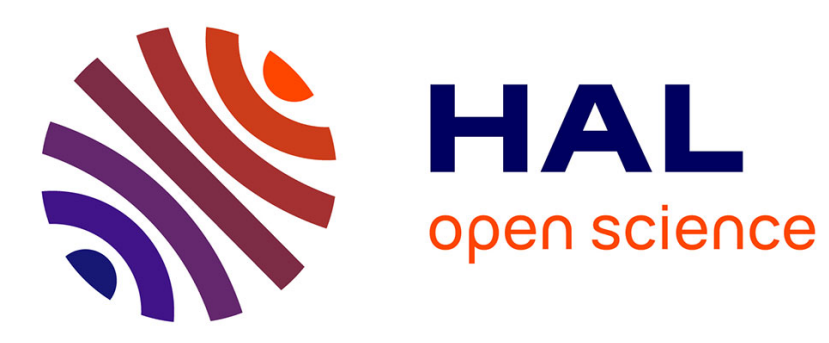

\title{
The rggC locus, with a frameshift mutation, is involved in oxidative stress response by Streptococcus thermophilus
}

Annabelle Fernandez, Frédéric Borges, Brigitte Gintz, Bernard Decaris, Nathalie N. Leblond-Bourget

\section{To cite this version:}

Annabelle Fernandez, Frédéric Borges, Brigitte Gintz, Bernard Decaris, Nathalie N. Leblond-Bourget. The rggC locus, with a frameshift mutation, is involved in oxidative stress response by Streptococcus thermophilus. Archives of Microbiology, 2006, 186 (3), pp.161 - 169. 10.1007/s00203-006-0130-8 . hal-01631247

\section{HAL Id: hal-01631247 \\ https://hal.univ-lorraine.fr/hal-01631247}

Submitted on 9 Nov 2017

HAL is a multi-disciplinary open access archive for the deposit and dissemination of scientific research documents, whether they are published or not. The documents may come from teaching and research institutions in France or abroad, or from public or private research centers.
L'archive ouverte pluridisciplinaire HAL, est destinée au dépôt et à la diffusion de documents scientifiques de niveau recherche, publiés ou non, émanant des établissements d'enseignement et de recherche français ou étrangers, des laboratoires publics ou privés. 


\section{The rggC locus, with a frameshift mutation, is involved in oxidative} stress response by Streptococcus thermophilus

Annabelle Fernandez, Frédéric Borges, Brigitte Gintz, Bernard Decaris and

Nathalie Leblond-Bourget*

(1)

$\mid \begin{aligned} & \text { Laboratoire de Génétique et Microbiologie, UMR INRA 1128, IFR 110, Faculté des Sciences } \\ & \text { et Techniques de l'Université Henri Poincaré, Campus de Grignard, BP239, } 54506 \\ & \text { Vandœuvre-lès-Nancy, France } \\ & \text { *Corresponding author: Tél: (33)383684210 - Fax: (33)383684499 } \\ & \text { email: } \underline{\text { bourget@nancy.inra.fr }}\end{aligned}$ 
In Streptococcus thermophilus, the locus rggC contains a frameshift mutation and thus consists of two ORFs, $r g g C_{1}$ and $r g g C_{2}$ which encode proteins exhibiting similarity with the Rgg transcriptional regulator family. In this work, mutants showing a partial deletion of $r g g C_{1}$ and $\operatorname{rggC}_{2}$ were constructed and their response to menadione, a superoxide generating compound, was analysed. These mutants exhibited different behaviour to this oxidative stress compared to the wild-type strain. Analysis of this locus among 21 strains of S. thermophilus showed a polythymine tract length variability and a strain dependant adenine residue could be found upstream of this repeat. This inter-strain polymorphism supports evidence for the hypothesis that the $\operatorname{rggC}$ locus is phase variable.

Key words: Streptococcus thermophilus, oxidative stress response, transcriptional regulator, Rgg, genetic variability, frameshift mutation 
The genus Streptococcus is composed of numerous pathogenic species and the food grade species S.thermophilus which is used as a starter of fermentation in yogurt and cheese production. During the biotransformation process, the formation of reactive oxygen species (ROS) may occur and be deleterious to the cells. S. thermophilus is an anaerobic aerotolerant organism that can grow in presence of oxygen and survive in low concentrations of superoxide and hydroxyl radicals (Thibessard et al. 2001). This suggests that it has developed strategies for cell detoxication and damage repair caused by ROS.

Recently, the genome sequences of two S. thermophilus strains LMG18311 and CNRZ1066 were completed (Bolotin et al. 2004) and putative genes involved in oxidative stress defence were identified by genomic analysis (Hols et al. 2005). Genes in the disulfide-reducing pathway like glutathione reductase, thioredoxin or thioredoxin reductase have been detected. These genes products help to maintain the redox state of the cell and allow reducing intracellular disulfide. S. thermophilus antioxidant defence also comprises genes encoding enzymes that detoxify oxygen or ROS. Thus, the $\mathrm{S}$. thermophilus genome encodes an $\mathrm{H}_{2} \mathrm{O}$-forming NADH oxidase, an essential enzyme for the $\mathrm{NAD}^{+}$regeneration during aerobic growth (Higuchi et al. 1999). In Streptococcus mutans, induction of $\mathrm{H}_{2} \mathrm{O}$-forming $\mathrm{NADH}$ oxidase protects cells against oxygen toxicity (Higuchi 1992). S. thermophilus also encodes a superoxide dismutase thought to catalyze superoxide radicals dismutation in $\mathrm{O}_{2}$ and $\mathrm{H}_{2} \mathrm{O}_{2}$. Although deprived of $\mathrm{H}_{2} \mathrm{O}_{2}$ detoxifying enzymes like catalase, NADH-peroxidase or alkyl hydroperoxidase, S. thermophilus possess an $\mathrm{H}_{2} \mathrm{O}_{2}$ defence system to reduce damage induced by this compound. This system could include psaD and $d p r$ genes. PsaD is encoding a thiol-peroxidase and Dpr is an iron-binding protein required for oxygen tolerance in S. mutans (Yamamoto et al. 2004). Dpr iron sequestration activity is thought to prevent the formation of toxic hydroxyl radicals via the Fenton reaction (Niven and Ekins 2001; Yamamoto et al. 2002; Pulliainen et al. 2003; Yamamoto et al. 2004; Pulliainen et al. 2005). Valuable information on S. thermophilus oxidative stress processes have also acquired by genetic approach using random IS mutagenesis. 
Inactivation of several genes involved either in cell wall metabolism, exopolysaccharide translocation, tRNA modification, purine metabolism, or iron metabolism have been implicated in cell survival during oxidative stress (Thibessard et al. 2004).

Among the well characterised oxidative stress-regulators in other organisms such as OxyR, PerR, sigma(B) and OhrR, controlling the peroxide response (for reviews: Hecker and Volker 1998; Mongkolsuk and Helmann 2002) and the superoxide stress response system SoxRS (Demple 1996)only perR, is present in the S. thermophilus genome.

In pathogenic streptococci, several regulators involved in oxidative stress have been described. Among these regulatory proteins is RopA, a key regulator of acid and oxidative stress tolerance, genetic competence, biofilm formation and virulence in S. mutans (Wen et al. 2005). In Streptococcus pneumoniae, the perception of $\mathrm{O}_{2}$ deprivation is associated with DNA uptake and controlled by $\mathrm{CiaRH}$ and MicAB two-component systems (Echenique et al. 2000; Echenique and Trombe 2001). Both ropA and micAB genes have been identified in the S. thermophilus genome (Bolotin et al. 2004). Additional to this list are the regulatory factors belonging to the Rgg family. These proteins are only found in Streptococcus and few other low-GC Grampositive genera, such as Listeria, Lactobacillus and Lactococcus. In S. pyogenes, Rgg interacts with regulatory networks to co-regulate virulence factor expression (Chaussee et al. 2001) and has also been implicated in oxidative and thermic stress responses as well as in the synthesis or stability of growth phase-regulated proteins associated with amino-acid metabolism (Chaussee et al. 2004).

In order to characterise S. thermophilus oxidative stress tolerance molecular basis, we previously used a random IS mutagenesis approach to produce mutants and screened them for their potential impaired tolerance to menadione (a superoxide generating compound). This strategy led us to identify 18 S. thermophilus CNRZ368 mutants (Thibessard et al. 2004). One of which is rggC. This gene is known to contain a frameshift mutation from the S. thermophilus genome sequence. This work is focused on $\mathrm{rggC}$ and attempts to determine how such a locus inactivated by a frameshift mutation is involved in oxidative stress tolerance. The $\operatorname{rggC}$ locus 
analysis was performed by engineering partial deletions of this locus and examining the ability of mutants to survive in the presence of menadione. Our results support an active role for $\mathrm{RggC}$ in S. thermophilus oxidative stress response.

\section{MATERIALS AND METHODS}

\section{Bacterial strains growth conditions}

The bacterial strains used in this study are listed in Table 1. Streptococcal strains including wild-type and mutant strains were cultured either in M17 (Terzaghy and Sandine 1975), or TPPY (a Tryptose, Proteose Peptone, Yeast extract containing medium) (Bracquart 1981) or milk mediums, at $30^{\circ} \mathrm{C}$ or $42^{\circ} \mathrm{C}$, depending on the experiments requirement. When appropriate, these media were supplemented with antibiotics at the following concentrations: erythromycin at $2 \mu \mathrm{g} \cdot \mathrm{ml}^{-1}$, and chloramphenicol at $3 \mu \mathrm{g} \cdot \mathrm{ml}^{-1}$.

E. coli EC101 was used for cloning experiments and transformed by electroporation with various plasmids as indicated below. E. coli strains were grown on Luria-Bertani (LB) medium (Sambrook et al. 1989) and the following selective antibiotics were added, when needed: erythromycin $\left(150 \mu \mathrm{g} \cdot \mathrm{ml}^{-1}\right)$, chloramphenicol $\left(15 \mu \mathrm{g} \cdot \mathrm{ml}^{-1}\right)$ or ampicillin $\left(100 \mu \mathrm{g} \cdot \mathrm{ml}^{-1}\right)$.

\section{DNA manipulations}

Isolation of genomic or plasmid DNA, agarose gel electrophoresis, restriction enzyme digestions, Southern hybridisation, PCR, DNA ligation and E. coli transformation were performed as described in Sambrook et al. (1989). Sequencing was carried out with the DNA sequencing kit (Applied Biosystems) on an ABI Prism 377 Genetic Analyser (Applied Biosystems). Sequence data were analysed with Blast, ProDom and TIGRfam Model software. The $\operatorname{rggC}_{1}$ and $\mathrm{rggC}_{2}$ DNA sequences have previously been deposited in GenBank under accession numbers from AY598750. The orf2 and $\underline{r s p}$ DNA sequences obtained in this work were deposited under accession number AM087201. 
3. RNA manipulations

RNA was extracted from $S$. thermophilus CNRZ368overnight $\left(\mathrm{OD}_{600}=1.6\right)$ cultures with a single guanidinium thiocyanate step and phenol-chloroform extraction by using the Tri-Reagent (Sigma). Northern blot hybridisation analysis, templates of RNA samples $(30 \mu \mathrm{g})$ were electrophoresed into a denaturing (i.e. formaldehyde) $1.1 \%$ agarose gel and transferred to a HybondN $^{+}$(Amersham pharmacia biotech) according to the manufacturer's instructions. Digoxigenin-labelled transcripts complementary to $\mathrm{rgg}_{2}$ were used as a probe. These $r g g C_{2}$ transcripts were synthesised in vitro using the T3 promoter RNA polymerase system carried by the pBKS-rggC $C_{2}$ vector. The latter was constructed by cloning a $533 \mathrm{bp}$ internal fragment of $\operatorname{rggC}_{2}$ (nucleotides 932 to 1464 ) in the pBKS vector. Hybridisation and detection procedures were performed according to manufacturer's instructions (Roche Molecular Biochemicals). RTPCR experiments were carried out as previously described (Fernandez et al. 2004). Primers used in PCRs were purchased from MWG Biotech AG (Ebersberg) and their sequences were 5' -AGGTGACTAGAATGAAATATGG-3' for P $_{1}$, 5' -TCCATTTGGCTAATTAATAGC-3' for $\mathrm{P}_{2}, \quad$ 5' $^{\prime}$-TATTGCTGCCACGAAATTGGT-3' ${ }^{\prime}$ for $\mathrm{P}_{3}$ and 5' -CACCGCCACAAGAATGACTT-3' for $\mathrm{P}_{4}$. Primers used in rggC locus sequencing were 5' -AGGAGGTGACTAGAATGAAATATGG-3' ${ }^{\prime}$ for $\quad$ V1 5' -TCCATTTGGCTAATTAATAGC-3' for V2.

\section{Constructions of $\Delta r g g C_{1}, \Delta r g g C_{2}$, orf2 and $r g g C_{8 T}$ mutants}

The $\Delta r g g C_{1}$ gene contained a deletion of $43 \%$ of the CDS. A stop codon (TAA) was inserted between the potential RBS of $r g g C_{1}$ and the start codon of $r g g C_{2}$ to prevent using this RBS sequence for $\operatorname{RggC}_{2}$ translation. The 5' and 3' ends of the $\operatorname{rggC}_{1}$ gene were independently amplified with the following sets of primers: 5' -CTTGCTTTGAATTCCAGGCT-3' (named I ${ }_{1}$ ) and $5^{\prime}$-TAAAGATAAAGCTTAAGATTCTC-3' for the ${ }^{\prime}$ ' region; 
(named $\mathrm{I}_{2}$ ), for the 3' region (engineered restriction sites are underlined, stop codon is in boldface type). Amplified fragments were digested with HindIII and ligated to each other. The resulting fragment was amplified, digested with EcoRI and cloned into pGh9 vector to produce pGh9 $\operatorname{rgg} C_{1}$ plasmid. The same procedure was used to produce pGh9 $\operatorname{rgg} C_{2}$ and pGh9orf2 $\mathrm{z} 1,2_{2}$ plasmids. pGh9 $\operatorname{\Delta rgg} C_{2}$ carried a $44 \%$ deletion of $r g g C_{2}$ and was constructed using the primers: 5' -TTATAAGAATTCAGGAGGTG-3' and 5' -TGATTTAAAGCTTCTATTGTAT-3' to amplify the 5' region; 5' -AAATGTAAAGCTTCCACGAAA-3' and 5' -AAATCCAGAATTCGATTATCC-3' for the 3' region.

The construction of the pGh9orf2z1,2 plasmid containing 2 stop codons (TAA, TAA) in the 2 first codons of orf2 was carried out using the following set of primers: 5' -TCGAAGAATTCGTTTACG-3' and 5' -TCACCTGAAGCTTATTACATGGT-3' for the 5' region;

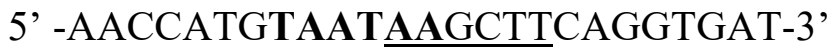
and 5' -TTTGATGAATTCTAGTATATGT-3' for the 3' region.

The pGh9rgg $C_{8 т}$ plasmid, carrying a thymine point deletion allowing a $\operatorname{Rgg} C_{1}-C_{2}$ fusion, was constructed. To generate this mutation, the 5' and 3' regions of rgg were amplified with the following sets of primers: $\mathrm{I}_{1}$ and 5' -CTAACGCTAAAAAAAATTTGCTG-3' for the 5' region; 5' -CAAATTTTTTTTAGCGTTAGATGC-3' and $\mathrm{I}_{2}$ for the 3' region. These 2 products were mixed together, used as templates in a PCR reaction to generate a full length fragment and cloned into pGh9 vector to produce the pGh9rggC $8 т$ plasmid. This recombinant plasmid DNA was extracted and used to transformed S. thermophilus CNRZ368 cells as previously described by (O'Sullivan and Fitzgerald 1999). Allelic gene replacements were done as previously described (Biswas et al. 1993) with the following modifications: the medium used for S. thermophilus growth was M17, 3 cycles of growth were carried out with two steps, one at $30^{\circ} \mathrm{C}$ (permissive temperature) and another one at $42^{\circ} \mathrm{C}$ (restrictive temperature). The chromosomal structure of mutant alleles was checked by PCR, southern blot analysis and sequencing. 


\section{Menadione assay}

S. thermophilus and its mutant derivatives were grown overnight in milk medium and diluted 100 times into TPPY liquid medium. Log-phase cultures $\left(\mathrm{OD}_{600}=0.6\right)$ were exposed for $3 \mathrm{~h}$ to menadione concentrations ( 0 to $72 \mathrm{mM})$. Aliquots of the culture were then diluted in TPPY and appropriate dilutions plated on TPPY agar plates. The plates were stocked in jars containing a GENbox anaer system (bioMérieux) providing hypoxic conditions. Colony-forming units (CFU) were counted after $20 \mathrm{~h}$ of incubation and the percentage of surviving CFUs was determined by comparing viability with or without treatment. All experiments were performed independently at least three times.

\section{RESULTS}

\section{Characterisation of the disrupted loci in osrC genome}

In a previous study, the osrC mutant of S. thermophilus CNRZ368 was characterised in its resistance to menadione, a superoxide-generating agent (Fernandez et al. 2004). In this mutant, pGhost9::ISS1 was inserted in $\mathrm{rggC}_{2}$ region. The $\mathrm{rggC}_{1} \mathrm{ORF}$ encodes a predicted 65 aa protein exhibiting $77 \%$ identity to the C-terminal region of S. mutans Rgg. The second ORF, $\mathrm{rggC}_{2}$ encodes a putative 232 aa protein sharing $54 \%$ identity with the N-terminal region of S. mutans Rgg. These two ORFs could initially have constituted a single ORF, having undergone a frameshift mutation (Fig.1A). This mutational event would have occurred between positions 886 to 894 , where a 9-mer (TTT TTT TTT) known to be genetically unstable is observed. Ribosomebinding site (RBS) consensus sequence (AAAGGAGG in Gram-positive bacteria) scan revealed a potential RBS (AGGAGG) located 8 bp upstream rggC1. No canonical RBS sequencepreceding $\mathrm{rggC}_{2}$ was detected upstream of the first putative start codon or within the CDS of $\operatorname{rgg}_{1}$. These results suggest that only $\operatorname{RggC}_{1}$ or a full fusion protein $\operatorname{RggC}_{1-2}$, could be produced, indicating a translational or transcriptional frameshifting.

Since Rgg proteins often regulate adjacent genes (Sulavik and Clewell 1996; Lyon et al. 1998; Chaussee et al. 1999; Qi et al. 1999; Neely et al. 2003), the ORFs localised downstream of 
the $r g g C$ locus were analysed. $\operatorname{Rgg}_{2}$ is followed by a small ORF, $\operatorname{orf}_{2}$ that encodes a putative 35 aa protein with no significant homology to any database sequences. orf 2 is preceded by a canonical RBS with the sequence, AAAGGAGG suggesting it was expressed. Downstream orf2, there is an $r s p$ gene (for radical $\underline{S} A M$ protein) that encodes a putative protein sharing $29 \%$ identity (46\% similarity) with a possible Fe-S oxidoreductase of Thermoanaerobacter tengcongensis belonging to the radical SAM protein family (Sofia et al. 2001). A RBS sequence (GGAGG) was also found upstream rsp.

The transcriptional signals scan analysis allowed us to identify a potential promoter (TATGATATAAT), located $61 \mathrm{bp}$ upstream of $r g g C_{1}$, and constitute an extended -10 region (Voskuil and Chambliss 1998). Moreover, a putative rho-independant terminator consisting of a perfect inverted repeat of $10 \mathrm{bp}$ followed by a stretch of T's, was visualized $9 \mathrm{bp}$ downstream of the $\operatorname{orf}_{2}$ stop codon. A potential promoter located upstream $r s p$ was identified including a -10 (TGTAAT) and a -35 (TTTAGA) region with a 15 bp spacer.

\section{Transcriptional analysis of the rggC locus}

Northern blot analysis using $\mathrm{rggC}_{2}$ antisense-RNA (nucleotides 932 to 1464 ) as a probe was performed on RNA extracted from stationary phase cells. One transcript of approximately 1200 nucleotides was detected (Fig.1B). Since the $\mathrm{rggC}_{2}$ gene size is $0.7 \mathrm{~kb}$, this transcript observation is compatible with the polycistronic transcription of $\mathrm{rggC}_{2}$ with the neighbouring ORFs.

To better characterise this transcript, RT-PCR analyses were carried out. cDNA generated from S. thermophilus CNRZ368 RNA were used in PCRs experiments using primers $\mathrm{P}_{1} / \mathrm{P}_{2}$ and $\mathrm{P}_{3} / \mathrm{P}_{4}$ localized in $\mathrm{rggC}_{1} / \mathrm{rggC}_{2}$ and $\mathrm{rggC}_{2} /$ orf2 respectively (Fig. $1 \mathrm{C}$ ). In both cases, a PCR product of the expected size (310 bp and $265 \mathrm{bp}$ respectively) was amplified suggesting the existence of at least one transcript including $r g g C_{1}, r g g C_{2}$ and $\operatorname{orf} 2$. The transcript size was in agreement with the transcription signals visualized on the sequence. 


\section{Involvement of the rggC locus in the oxidative stress defence}

Since $\operatorname{rggC}$ locus exhibits operon structure, the resistance phenotype could be either the result of the inactivation of $r g g C_{2}$ gene or/and the result of polar effects on the $\operatorname{rggC}_{1}$ and orf2 neighbouring genes. In this study, non-polar $\operatorname{\Delta rgg} C_{1}, \Delta r g g C_{2}$ and orf2 mutants were constructed via allelic replacement and their survival in presence of menadione was studied (see materials and methods). Compared to the reference strain, the $\Delta r g g C_{1}$ mutant displayed a 2-fold higher resistance following exposure to menadione at concentrations of $27 \mathrm{mM}$ and $36 \mathrm{mM}$ (Fig. 2A). The $\operatorname{ArggC}_{2}$ mutant exhibited a 2-fold decreased of surviving cells at a menadione concentration of $9 \mathrm{mM}, 18 \mathrm{mM}$ and $27 \mathrm{mM}$ (Fig. 2B). Thus, a decreased survival was observed for the $\Delta r g g C_{2}$ mutant, while the survival of the $\Delta r g g C_{1}$ strain was enhanced indicating the involvement of both of these ORFs in S. thermophilus oxidative stress response. In contrast, orf2 mutant survival was the same as the reference strain (data not shown) suggesting that orf 2 was not involved in this pathway.

\section{Intraspecific polymorphism of rggC potential shift site}

The analysis of the DNA sequence of the $r g g C$ locus predicted 2 ORFs: $r g g C_{1}$ and $r g g C_{2}$. A sequence of 9 T's was observed at the 3'end of $r g g C_{1}$. Since such mononucleotide repeats are known to exhibit high frequencies of nucleotide deletion or insertion events, the potential polymorphism of the $\mathrm{rggC}$ shift site was investigated among 21 strains $S$. thermophilus. The $\operatorname{rggC}_{1}$ gene was shown to be present in all 21 studied strains, using PCR amplification with primers V1 and V2 designed to bind the 5' part of $\operatorname{rggC}_{1}$ and the central part of $\operatorname{rggC}_{2}$, respectively. The frameshift mutation of $\mathrm{rggC}_{1}$ was analysed by sequencing the PCR products with primer V1. Four different sequences were found varying from 7 to 9 T's (Table 2). A deletion of one A upstream of the T tract in rggC from CNRZ1402, CNRZ455 and LMD9 strains was also observed. The strain ATCC1958 is characterised by the presence of 8 instead of 9 Ts. 
This mutation would result in formation of an in-frame ORF, allowing potentially full-length $\mathrm{RggC}$ protein translation whereas in all the other cases a $\mathrm{RggC}_{1}$ protein was expected.

\section{Involvement of RggC in oxidative stress defence of S. thermophilus CNRZ368}

To determine the involvement in oxidative stress defence of a full-length $\mathrm{RggC}$ protein, an additional $\mathrm{rgg}_{8 т}$ mutant was constructed via allelic replacement. This mutant from CNRZ368 contains an eight $\mathrm{T}$ chromosomal sequence. Its survival in the presence of different concentrations of menadione was determined and showed to be reduced at a menadione concentration of $18 \mathrm{mM}, 27 \mathrm{mM}$ and $36 \mathrm{mM}$ compared to wild-type confirming a role for rggC in S. thermophilus CNRZ368 oxidative stress response (Fig. 3).

\section{DISCUSSION}

Among the fully sequenced streptococcal genomes, that of S. thermophilus exhibits the highest proportion of pseudogenes. Indeed, $10 \%$ of the S. thermophilus genes are characterised by frameshift, nonsense mutation, deletion or truncation and are therefore considered as non functional (Bolotin et al. 2004). Here, we examined $\mathrm{rggC}$, considered in S. thermophilus as a pseudogene, and we demonstrated its role in S. thermophilus oxidative stress response.

In osrC mutant, the disruption of $\operatorname{rggC}_{2}$, with pGh9:ISS1, confers to the cells a resistance to menadione. This insertion mutant shows a polar mutation affecting the transcript stability of the $\operatorname{rggC}$ locus and of the neighbouring $r s p$ gene.

To understand this phenomenon, deletions of $\mathrm{rggC}_{1}$ and $\mathrm{rggC}_{2}$ were undertaken and demonstrated that both ORFs were involved in oxidative stress response. However, these 2 mutants displayed 2 distinct phenotypes: one being resistant and the other sensitive to oxidative stress. Two alternative hypotheses can explain this. Firstly, the 2 proteins $\operatorname{RggC}_{1}$ and $\mathrm{RggC}_{2}$ could be synthesised and would be characterised by different activities. Nevertheless, the lack of a RBS sequence-preceding $\mathrm{rggC}_{2}$ is a strong argument in disfavour of this hypothesis. Secondly, 
the $\operatorname{srggC}_{2}$ phenotype could result from the synthesis of a full $\mathrm{RggC}$ protein by frameshifting as observed in translational or transcriptional slippage (for review : Baranov et al. 2005).

Taking all these data into account, both $\mathrm{RggC}_{1}$ and $\mathrm{RggC}$ proteins are likely to be synthesised in the wild type strain.

In CNRZ368 strain, a stretch of $9 \mathrm{~T}$ residues could allow a transcriptional slippage, and consequently lead to the $\mathrm{RggC}$ fusion protein by translation of a subpopulation of $\mathrm{rggC}$ transcript in the alternate reading frame. Alternatively, since RNA-DNA hybrids of 9 are described as genetically unstable they could provide RNA polymerase slippage by re-alignment of the nascent RNA chain and its DNA template (Wagner et al. 1990). Few examples of transcriptional slippage are identified in prokaryotes. In Thermus thermophilus, $\tau$ and $\gamma$ subunit proteins of DNA polymerase III are synthesized from dnaX gene by this mechanism. This ORF shows 9 adenine residues allowing the slippage of RNA polymerase and producing many mRNAs with additional or subtractive adenine residues (Larsen et al. 2000). In Shigella flexneri, the mixE gene, encoding a transcription activator, consists of 2 overlapping ORFs. A track of 9 thymine residues is observed at the site of overlapping. Transcriptional incorporation of one additional nucleotide allows synthesis of the functional MixE protein (Penno et al. 2005).

The putative $\mathrm{RggC}$ protein belongs to the family of $\mathrm{Rgg}$-like transcriptional regulators. $\mathrm{RggC}_{1}$ displayed the typical N-terminal helix-turn-helix motif suggestive of a DNA-binding function. Among characterised Rgg-like proteins, rgg from Streptococcus gordonii, rgg and ropB from S. pyogenes are located immediately adjacent to their regulatory target sequence (Sulavik and Clewell 1996; Lyon et al. 1998; Chaussee et al. 1999; Qi et al. 1999; Neely et al. 2003). Thus, the transcriptional expression of orf2 and rsp ORFs from S. thermophilus CNRZ368 was analysed by quantitative RT-PCR in $\Delta r g g C_{1}, \Delta r g g C_{2}$ and wild-type genetic contexts (data not shown). Partial deletion of rggC locus did not affect the expression of orf2 and rsp ORFs compared with the level seen in the wild type CNRZ368 strain. However, S. thermophilus genome contains $7 \mathrm{rgg}$ genes (Bolotin et al. 2004). It is therefore possible that one of the Rgg proteins replace $\mathrm{RggC}$ function in the defective strain. Moreover, it still is possible that $\mathrm{RggC}$ 
directly or indirectly regulates the transcription of other genes since deletion of rgg from S. pyogenes has been demonstrated to have genome wide effects on virulence-associated transcription (Chaussee et al. 2001; Chaussee et al. 2002).

Analysis of 21 S. thermophilus rgg sequences revealed a polymorphism of the $9 \mathrm{~T}$ residue region. Repeats of a single or several nucleotides, named microsatellite DNA, are involved in numerous phase variation events that could be defined as a high-frequency and reversible mechanisms of gene-switching (for review: (Hallet 2001). This inter-strain length polymorphism supports evidence for the phase variability of the $\operatorname{rggC}$ locus. Some cases of phase variation have been identified in the Streptococcus genus, allowing the control of transcriptional or translational expression (Lukomski et al. 2001; Puopolo and Madoff 2003). A phase variation event at the rggC locus could influence a potential programmed frameshifting by inactivation.

In $20 / 21$ cases, a +1 or -1 frameshift mutation was observed resulting in a 'gene off' configuration. If the full-length $\mathrm{rggC}$ ORF was an ancestral allele, it is possible that alleles showing this frameshift mutation may have been selected for a growth advantage associated with the loss of $\mathrm{rggC}$ function. The menadione sensitivity phenotype observed for the $\mathrm{rggC}_{8 \mathrm{~T}}$ mutant (whose $\mathrm{rggC}$ phase is restored) argued in the favour of that hypothesis.

The results of this study indicate the involvement of the rggC locus in S. thermophilus CNRZ368 oxidative stress response. Accordingly, the Rgg transcriptional regulatory protein from S. pyogenes that coordinates virulence factor synthesis and catabolic activity (Chaussee et al. 2003) was also demonstrated to be involved in thermal and in oxidative stress response (Chaussee et al. 2004). The S. pyogenes rgg mutant strain was more susceptible than wild-type to paraquat (a hydroxyl ion radicals generating compound) and was characterised by an elevated level of the oxidoreductases AhpC and Nox1 (Chaussee et al. 2004). All these data suggest a role for the Rgg family members in oxidative stress response, and more generally that these proteins may be important in the streptococcus adaptation to environmental changes. 
329 A.F. was supported by grants from the Ministère de la recherche. F.B. was supported by a 330 grant from the Institut National de la Recherche Agronomique. We are grateful to Arran Johnson 331 for his advice regarding the English formulation of the manuscript. 
Baranov PV, Hammer AW, Zhou J, Gesteland RF, Atkins JF (2005) Transcriptional slippage in bacteria: distribution in sequenced genomes and utilization in IS element gene expression. Genome Biol 6:R25

Biswas I, Gruss A, Ehrlich SD, Maguin E (1993) High-efficiency gene inactivation and replacement system for gram-positive bacteria. J Bacteriol 175:3628-3635

Bolotin A et al. (2004) Complete sequence and comparative genome analysis of the dairy bacterium Streptococcus thermophilus. Nat Biotechnol 22:1554-1558

Bracquart P (1981) An agar medium for the differential enumeration of Streptococcus thermophilus and Lactobacillus bulgaricus in yoghurt. Journal of Applied Bacteriology 51:303-305

Chaussee MA, Callegari EA, Chaussee MS (2004) Rgg regulates growth phase-dependent expression of proteins associated with secondary metabolism and stress in Streptococcus pyogenes. J Bacteriol 186:7091-7099

Chaussee MS, Ajdic D, Ferretti JJ (1999) The rgg gene of Streptococcus pyogenes NZ131 positively influences extracellular SPE B production. Infect Immun 67:1715-1722

Chaussee MS, Somerville GA, Reitzer L, Musser JM (2003) Rgg coordinates virulence factor synthesis and metabolism in Streptococcus pyogenes. J Bacteriol 185:6016-6024

Chaussee MS et al. (2002) Rgg influences the expression of multiple regulatory loci to coregulate virulence factor expression in Streptococcus pyogenes. Infect Immun 70:762-770

Chaussee MS, Watson RO, Smoot JC, Musser JM (2001) Identification of Rgg-regulated exoproteins of Streptococcus pyogenes. Infect Immun 69:822-831

Demple B (1996) Redox signaling and gene control in the Escherichia coli soxRS oxidative stress regulon--a review. Gene 179:53-57

Echenique JR, Chapuy-Regaud S, Trombe MC (2000) Competence regulation by oxygen in Streptococcus pneumoniae: involvement of ciaRH and comCDE. Mol Microbiol 36:688-696

Echenique JR, Trombe MC (2001) Competence modulation by the NADH oxidase of Streptococcus pneumoniae involves signal transduction. J Bacteriol 183:768-772

Fernandez A, Thibessard A, Borges F, Gintz B, Decaris B, Leblond-Bourget N (2004) Characterization of oxidative stress-resistant mutants of Streptococcus thermophilus CNRZ368. Arch Microbiol 182:364-372

Hallet B (2001) Playing Dr Jekyll and Mr Hyde: combined mechanisms of phase variation in bacteria. Curr Opin Microbiol 4:570-581

Hecker M, Volker U (1998) Non-specific, general and multiple stress resistance of growth-restricted Bacillus subtilis cells by the expression of the sigmaB regulon. Mol Microbiol 29:1129-1136 
Higuchi M (1992) Reduced nicotinamide adenine dinucleotide oxidase involvement in defense against oxygen toxicity of Streptococcus mutans. Oral Microbiol Immunol 7:309-314

Higuchi M et al. (1999) Functions of two types of NADH oxidases in energy metabolism and oxidative stress of Streptococcus mutans. J Bacteriol 181:5940-5947

Hols P et al. (2005) New insights in the molecular biology and physiology of Streptococcus thermophilus revealed by comparative genomics. FEMS Microbiol Rev 29:435-463

Larsen B, Wills NM, Nelson C, Atkins JF, Gesteland RF (2000) Nonlinearity in genetic decoding: homologous DNA replicase genes use alternatives of transcriptional slippage or translational frameshifting. Proc Natl Acad Sci U S A 97:1683-1688

Leenhouts K (1995) Integration strategies and vectors. Dev Biol Stand 85:523-530

Lukomski S et al. (2001) Identification and characterization of a second extracellular collagen-like protein made by group A Streptococcus: control of production at the level of translation. Infect Immun 69:1729-1738

Lyon WR, Gibson CM, Caparon MG (1998) A role for trigger factor and an rgg-like regulator in the transcription, secretion and processing of the cysteine proteinase of Streptococcus pyogenes. Embo J 17:6263-6275

Maguin E, Prévost H, Ehrlich SD, Gruss A (1996) Efficient insertional mutagenesis in Lactococci and other Grampositive bacteria. Journal of Bacteriology 178:931-935

Mongkolsuk S, Helmann JD (2002) Regulation of inducible peroxide stress responses. Mol Microbiol 45:9-15

Neely MN, Lyon WR, Runft DL, Caparon M (2003) Role of RopB in growth phase expression of the SpeB cysteine protease of Streptococcus pyogenes. J Bacteriol 185:5166-5174

Niven DF, Ekins A (2001) Iron content of Streptococcus suis and evidence for a dpr homologue. Can J Microbiol 47:412-416

O'Sullivan TF, Fitzgerald GF (1999) Electrotransformation of industrial strains of Streptococcus thermophilus. J Appl Microbiol 86:275-283

Penno C, Sansonetti P, Parsot C (2005) Frameshifting by transcriptional slippage is involved in production of MxiE, the transcription activator regulated by the activity of the type III secretion apparatus in Shigella flexneri. Mol Microbiol 56:204-214

Pulliainen AT, Haataja S, Kahkonen S, Finne J (2003) Molecular basis of H2O2 resistance mediated by Streptococcal Dpr. Demonstration of the functional involvement of the putative ferroxidase center by sitedirected mutagenesis in Streptococcus suis. J Biol Chem 278:7996-8005

Pulliainen AT, Kauko A, Haataja S, Papageorgiou AC, Finne J (2005) Dps/Dpr ferritin-like protein: insights into the mechanism of iron incorporation and evidence for a central role in cellular iron homeostasis in Streptococcus suis. Mol Microbiol 57:1086-1100 
Puopolo KM, Madoff LC (2003) Upstream short sequence repeats regulate expression of the alpha C protein of group B Streptococcus. Mol Microbiol 50:977-991

Qi F, Chen P, Caufield PW (1999) Purification of mutacin III from group III Streptococcus mutans UA787 and genetic analyses of mutacin III biosynthesis genes. Appl Environ Microbiol 65:3880-3887

Sambrook J, Fritsch EF, Maniatis T (eds) (1989) Molecular cloning: a Laboratory Manual. Cold Spring Harbor Laboratory, New York

Sofia HJ, Chen G, Hetzler BG, Reyes-Spindola JF, Miller NE (2001) Radical SAM, a novel protein superfamily linking unresolved steps in familiar biosynthetic pathways with radical mechanisms: functional characterization using new analysis and information visualization methods. Nucleic Acids Res 29:10971106

Sulavik MC, Clewell DB (1996) Rgg is a positive transcriptional regulator of the Streptococcus gordonii gtfG gene. J Bacteriol 178:5826-5830

Terzaghy BE, Sandine WE (1975) Improved medium for lactic streptococci. Current Microbiology 7:245-250

Thibessard A, Borges F, Fernandez A, Gintz B, Decaris B, Leblond-Bourget N (2004) Identification of Streptococcus thermophilus CNRZ368 genes involved in defense against superoxide stress. Appl Environ Microbiol 70:2220-2229

Thibessard A, Fernandez A, Gintz B, Leblond-Bourget N, Decaris B (2001) Hydrogen peroxide effects on Streptococcus thermophilus CNRZ368 cell viability. Res Microbiol 152:593-596

Voskuil MI, Chambliss GH (1998) The -16 region of Bacillus subtilis and other gram-positive bacterial promoters. Nucleic Acids Res 26:3584-3590

Wagner LA, Weiss RB, Driscoll R, Dunn DS, Gesteland RF (1990) Transcriptional slippage occurs during elongation at runs of adenine or thymine in Escherichia coli. Nucleic Acids Res 18:3529-3535

Wen ZT, Suntharaligham P, Cvitkovitch DG, Burne RA (2005) Trigger factor in Streptococcus mutans is involved in stress tolerance, competence development, and biofilm formation. Infect Immun 73:219-225

Yamamoto Y, Fukui K, Koujin N, Ohya H, Kimura K, Kamio Y (2004) Regulation of the intracellular free iron pool by Dpr provides oxygen tolerance to Streptococcus mutans. J Bacteriol 186:5997-6002

Yamamoto Y, Poole LB, Hantgan RR, Kamio Y (2002) An iron-binding protein, Dpr, from Streptococcus mutans prevents iron-dependent hydroxyl radical formation in vitro. J Bacteriol 184:2931-2939 


\begin{tabular}{|c|c|c|}
\hline $\begin{array}{l}\text { Strains and } \\
\text { plasmids }\end{array}$ & Relevant feature(s) & Source and/or citation \\
\hline \multicolumn{3}{|l|}{ S. thermophilus } \\
\hline CNRZ007 & Wild-type strain & CNRZ, INRA strain collection \\
\hline CNRZ302 & Wild-type strain & CNRZ, INRA strain collection \\
\hline CNRZ307 & Wild-type strain & CNRZ, INRA strain collection \\
\hline CNRZ308 & Wild-type strain & CNRZ, INRA strain collection \\
\hline CNRZ368 & Wild-type strain & CNRZ, INRA strain collection \\
\hline CNRZ385 & Wild-type strain & CNRZ, INRA strain collection \\
\hline CNRZ388 & Wild-type strain & CNRZ, INRA strain collection \\
\hline CNRZ391 & Wild-type strain & CNRZ, INRA strain collection \\
\hline CNRZ445 & Wild-type strain & CNRZ, INRA strain collection \\
\hline CNRZ455 & Wild-type strain & CNRZ, INRA strain collection \\
\hline CNRZ702 & Wild-type strain & CNRZ, INRA strain collection \\
\hline CNRZ1066 & Wild-type strain & CNRZ, INRA strain collection \\
\hline CNRZ1068 & Wild-type strain & CNRZ, INRA strain collection \\
\hline CNRZ1402 & Wild-type strain & CNRZ, INRA strain collection \\
\hline ATCC19258 & Wild-type strain & $\underline{\text { American }} \underline{\underline{T}}$ pe $\underline{\text { Culture Collection }}$ \\
\hline ATCC19987 & Wild-type strain & 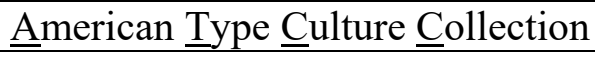 \\
\hline LMG18311 & Wild-type strain & $\overline{\mathrm{BCCM}} \mathrm{LMG}$ strain collection \\
\hline A054 & Wild-type strain & Lab collection \\
\hline IP6756 & Wild-type strain & Institut Pasteur strain collection \\
\hline IP6757 & Wild-type strain & Institut Pasteur strain collection \\
\hline osrC & $\begin{array}{l}\mathrm{Em}^{\mathrm{R}} \text { S. thermophilus CNRZ368 containing } \\
\text { integrated pGh9::ISS1 into rggC } 2\end{array}$ & ((Fernandez et al. 2004) \\
\hline$\Delta r g g C_{1}$ & $\begin{array}{l}\text { CNRZ368 strain carrying a deletion from nt } 50 \text { to } \\
127 \text { of } r g g C_{1}\end{array}$ & This study \\
\hline$\Delta r g g C_{2}$ & $\begin{array}{l}\text { CNRZ368 strain carrying a deletion from nt } 318 \\
\text { to } 619 \text { of } r g g C_{2}\end{array}$ & This study \\
\hline orf2 & $\begin{array}{l}\text { CNRZ368 strain carrying } 2 \text { stop codons in the } \\
\text { first codon of orf } 2\end{array}$ & This study \\
\hline $\operatorname{rgg} C_{8 T}$ & $\begin{array}{l}\text { CNRZ368 strain presenting an in-frame } r g g C \\
\text { gene }\end{array}$ & This study \\
\hline \multicolumn{3}{|l|}{ E. coli } \\
\hline EC101 & $\begin{array}{l}\text { TG1 derived strain [supE hsd-5 thi } \Delta(\text { lac-proAB) } \\
\left.\left.\text { F' (traD6proAB } B^{+} l a c I^{q} l a c Z \Delta M 15\right)\right] \text { containing a } \\
\text { chromosomal copy of the } \mathrm{pWV01} \mathrm{repA} \mathrm{gene}\end{array}$ & (Leenhouts 1995) \\
\hline \multicolumn{3}{|l|}{ Plasmid } \\
\hline pBKS & $A m p^{R}$ & Stratagene \\
\hline pGhost9 & $\begin{array}{l}\mathrm{Em}^{\mathrm{R}} \text {, thermosensitive replication origin from } \\
\text { pVE6002 }\end{array}$ & (Maguin et al. 1996) \\
\hline pGh9 $\operatorname{sgg} C_{1}$ & $\begin{array}{l}\text { pGh9 plasmid carrying } r g g C_{1} \text { deleted from } \\
\text { position } 50 \text { to } 127\end{array}$ & This study \\
\hline pGh9 $4 \operatorname{rgg} C_{2}$ & $\begin{array}{l}\text { pGh9 plasmid carrying } r g g C_{2} \text { deleted from } \\
\text { position } 318 \text { to } 619\end{array}$ & This study \\
\hline pGh9orf2z1,2 & $\begin{array}{l}\text { pGh9 plasmid carrying orf } 2 \text { with } 2 \text { stop codons } \\
\text { inserted in the first and the second codon }\end{array}$ & This study \\
\hline pGh9rgg $C_{8 T}$ & pGh9 plasmid carrying an in-frame $r g g C$ gene & This study \\
\hline
\end{tabular}


Table 2. Analysis of the rggC locus in 21 strains of $S$. thermophilus

\begin{tabular}{|c|r|c|}
\hline Sequence & Strain name & Mutation \\
\hline \multirow{2}{*}{ AGC AAA TTT TTT TTT AGC } & A054, ATCC19987, CNRZ007, & $+1 \mathrm{FS}$ \\
& CNRZ302, CNRZ307, CNRZ368, & \\
& CNRZ385, CNRZ388, CNRZ391, & \\
\hline AGC AAA_TT TTT TTT AGC & ATCC19258 & \\
\hline \multirow{2}{*}{ AGC AA__TT TTT TTT AGC } & CNRZ308, CNRZ445, CNRZ1066, & -1 FS \\
\hline AGC AA__T TTT TTT AGC & CNRZ455, CNRZ1402, LMD9 ${ }^{\mathrm{a}}$ & $+1 \mathrm{FS}$ \\
\hline
\end{tabular}

428

429

a according to sequence available htpp://www.jgi.doe.gov.

430 
Fig. 1 Organisation of the rggC locus of S.thermophilus CNRZ368. (A) The solid line represents the S. thermophilus genomic DNA. ORFs are indicated as open arrows. The broken arrow and the hairpin loop indicate the putative promoter and rho-independant terminator respectively. Putative RBS localisation is indicated by asterisks. Primers used for RT-PCR experiments are represented by small arrows under ORFs. The expected size of the $\mathrm{P}_{1}-\mathrm{P}_{2}$ and $\mathrm{P}_{3}-$ $\mathrm{P}_{4}$ PCR fragments is $310 \mathrm{bp}$ and $265 \mathrm{bp}$, respectively. ARN probe localisation is indicated by the black box. (B) Northern blot analysis of $r g g C_{2}$ transcripts. Left: gel electrophoresis staining wih ethidium bromide: lane 1 is RNA size marker and lane 2 is RNA $(30 \mu \mathrm{g})$ total extracted from S. thermophilus CNRZ368. 16S and 23S indicate the migrating positions of $16 \mathrm{~S}$ and $23 \mathrm{~S}$ rRNA, respectively. Right: result of the hybridisation with the $\operatorname{rggC}_{2}$ RNA probe. (C) Gel electrophoresis showing the RT-PCR products obtained using the primers $\mathrm{P}_{1}-\mathrm{P}_{2}$ and $\mathrm{P}_{3}-\mathrm{P}_{4}$. PstIdigested $\lambda$ DNA used as a DNA fragment size marker is indicated by $\lambda$ PstI.

Fig. 2 Survival of $\Delta r g g C_{1}$ and $\Delta r g g C_{2}$ mutants and the reference strain with increasing menadione concentrations. The graphs point the average values obtained from experiments performed at least in triplicate. The error bars represent standard deviations.

Fig. 3 Survival of $\operatorname{rggC}_{8 T}$ mutant and the reference strain with increasing menadione concentrations. The graphs point the average values obtained from experiments performed at least in triplicate. The error bars represent standard deviations 
Fig. 1

454

455

A

456

457

458

459

460

461

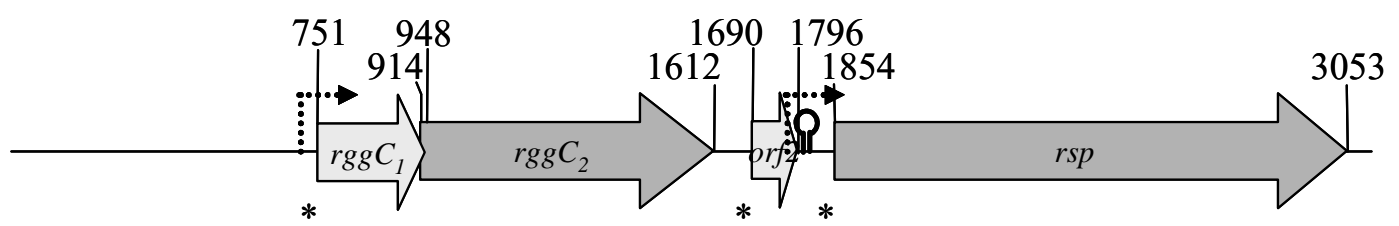

462

463

464

465

B

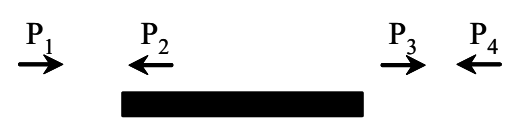

ARN probe
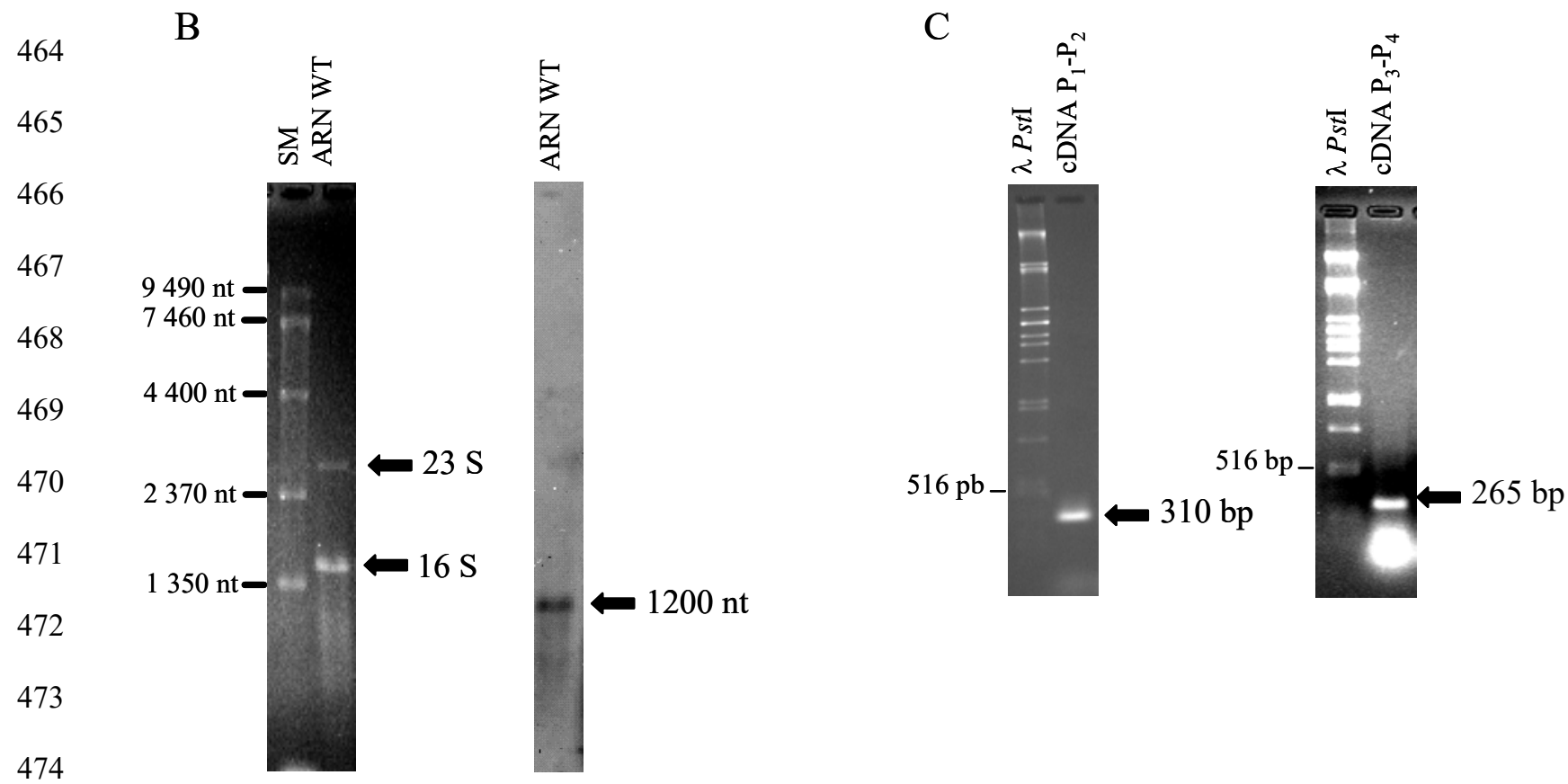

475

476

477

478

479

480

481 
Fig. 2

A

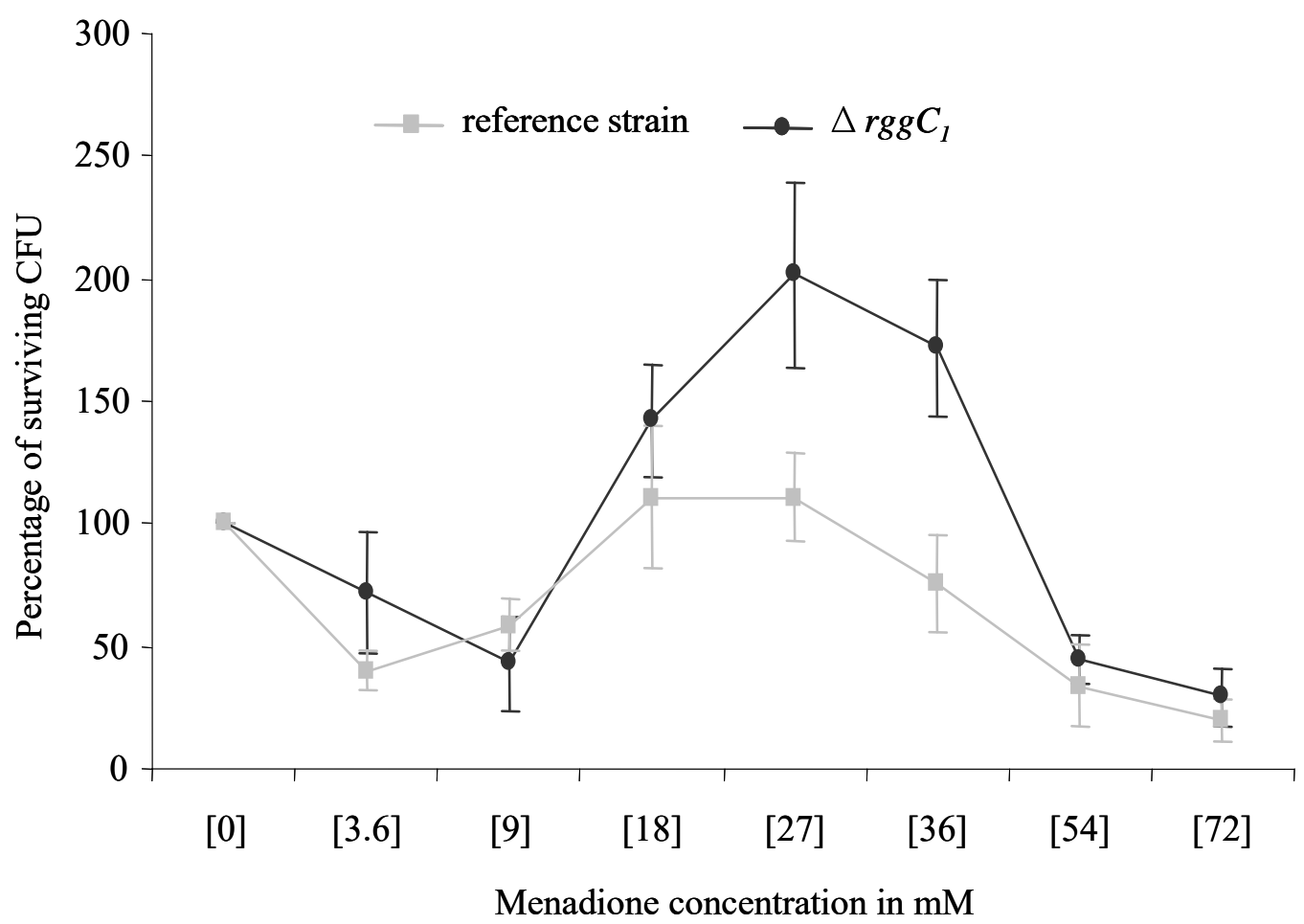

B

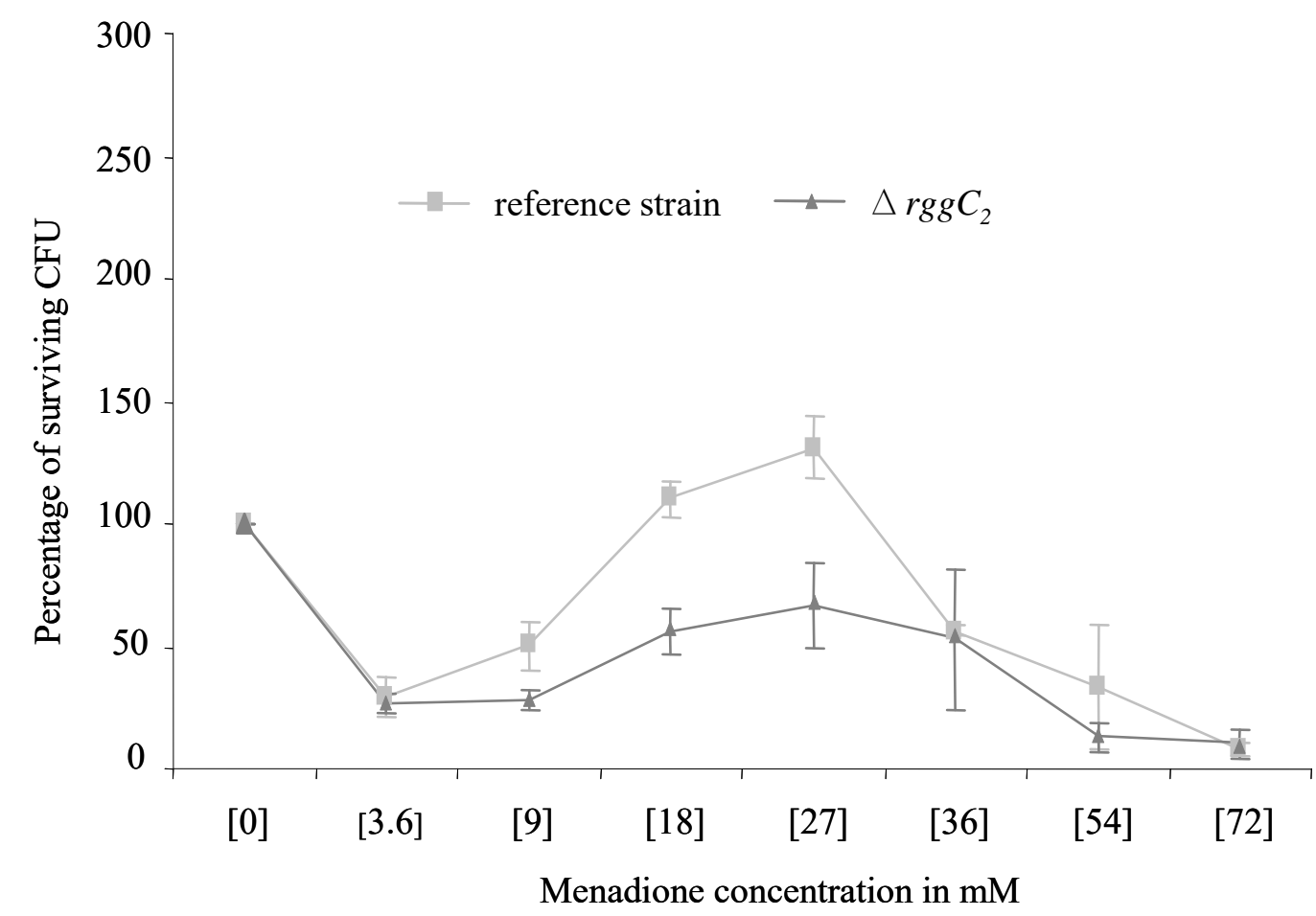


529

530

531

532

533

534

535

536

537

538

539

540
Fig. 3

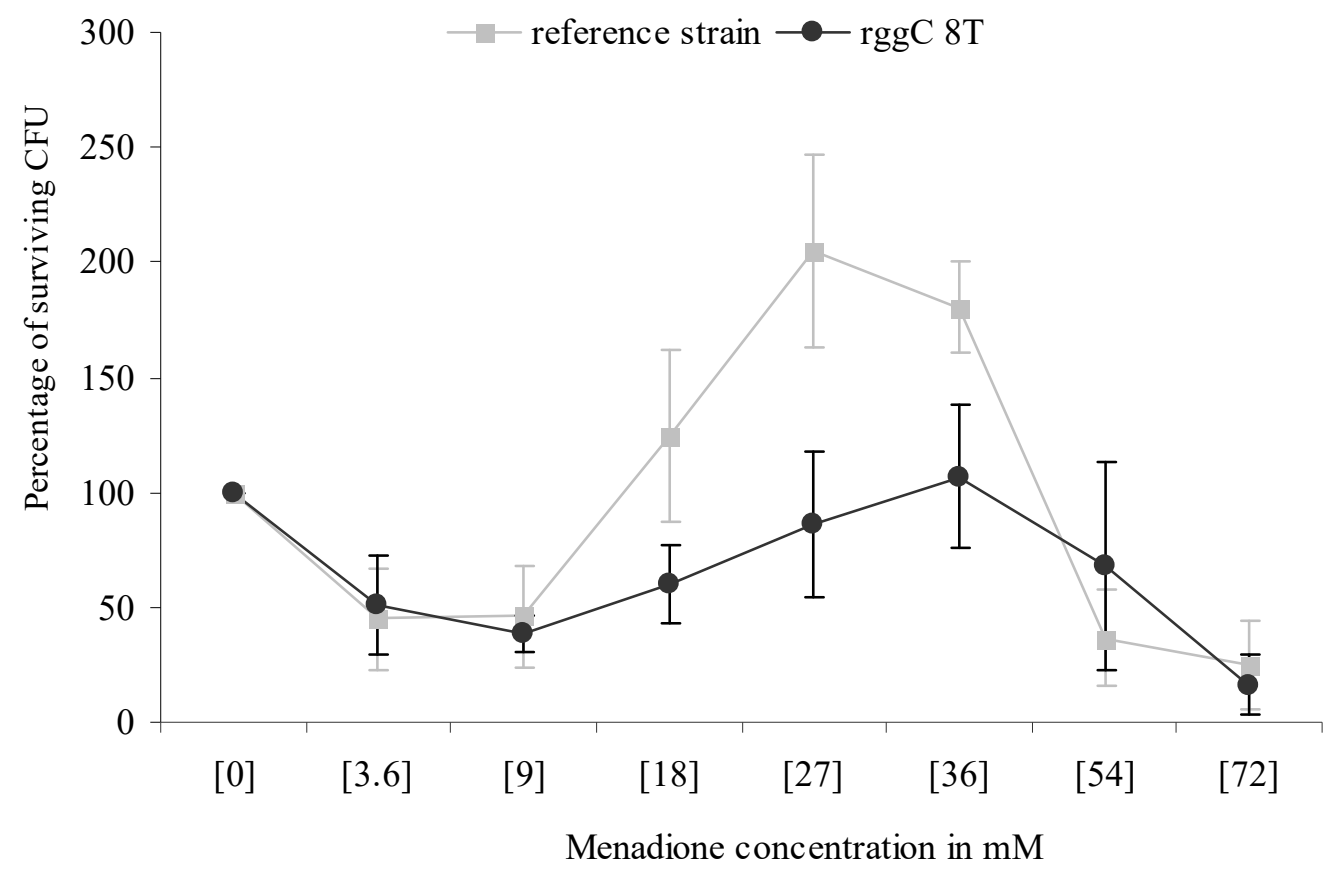

